\title{
A humanidade encontra sua irrelevância
}

\author{
EUGÊNIO BUCCI ${ }^{I}$
}

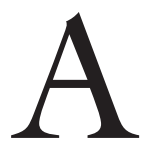

POLíticA de isolamento social em São Paulo começou oficialmente no início da segunda quinzena de março de 2020. Aos poucos, as aulas na USP passaram a ser oferecidas remotamente. Os professores tiveram de aprender aos chacoalhões, meio no tranco, como operar ferramentas virtuais que dessem conta de conectá-los com seus alunos, especialmente com aqueles que não contavam com wifi de boa qualidade. Foi um baque, mas a USP ficou de pé, não se vergou. No mais, a rotina acadêmica virou de ponta-cabeça. A pandemia de Covid-19, que já pusera em confinamento as populações de Wuhan, Madri, Veneza e outras localidades, começava a deixar as ruas paulistanas mais vazias de gente e mais cheias de dúvidas. Como ficaria a sociedade depois disso? Voltaríamos um dia à chamada "vida normal"?

Naquelas primeiras semanas da assim chamada "quarentena", circulavam discursos otimistas na praça. Ao menos três deles merecem lembrança agora: o primeiro, um tanto bucólico, dizia que o novo coronavírus nos levaria a valorizar as coisas simples da vida, como a vida em família; ${ }^{1}$ outras vozes entoavam um segundo discurso prevendo que, tão logo a peste passasse, as nações desenvolveriam novos pactos, mais sustentáveis, de convívio com a natureza; ${ }^{2}$ e, em terceiro lugar, vinha o discurso que antecipava o declínio dos populistas autoritários de direita que vinham menosprezando o poder devastador da doença. ${ }^{3}$

Claro que nenhuma dessas possibilidades - respeitáveis, justas e até desejáveis, cada uma em seus domínios - prescreveu. O recolhimento no lar, ao menos para alguns, proporciona uma sensação de acolhimento e conforto afetivo, embora, ao menos no Brasil, a maioria da população habite moradias sem espaço, sem dignidade, sem prazer, sem aconchego nenhum. De toda forma, onde o idílio doméstico é plausível, nada contra ele. No tocante às questões ecológicas, os ambientalistas não arredaram pé. Nem poderiam. Especialmente em nosso país, a iminência de uma dizimação das populações indígenas, diretamente relacionada ao avanço do desmatamento descontrolado (ou mesmo estimulado por autoridades federais), fazia da causa do meio ambiente um tema de urgência absoluta. Só os irresponsáveis evitavam e ainda evitam essa pauta, só os criminosos abrem fogo contra ela. Portanto, cerremos fileiras com os ambientalistas do Brasil e de todos os países. Por fim, quanto ao alegado desgaste dos populistas, notadamente de direita, tomara que se confirme. Se forem varridos pelas urgências de racionalidade e respeito à ciência, só nos restaria agradecer - teríamos, aí, um efeito colateral positivo, ao menos um, da pandemia. 
Isso posto, há um dado intrigante aí. Vistos em conjunto, os três discursos otimistas (há outros, que não serão aqui mencionados) parecem apontar na direção de um - usemos o clichê - mundo melhor, de um devir acentuadamente utópico, o que dá a essas falas um certo sabor de wishful thinking. Essa mirada esperançosa sobre a catástrofe sanitária teria algum sentido objetivo?

Em termos, talvez. É bem verdade que que, nessa temporada, surgiram indícios éticos menos desanimadores. Um exemplo foi a forma social de enfrentamento de contágio da Covid-19, que apelava não para o individualismo, não para o egoísmo, mas para a preocupação com o semelhante. Logo no início, os governos normais, sensatos, notaram que só dispunham de uma fórmula para deter o avanço dos contágios: limitar a circulação das pessoas, pedir para que todo mundo ficasse em casa. E como os governos normais, aqueles que não são liderados por facínoras, estabelecem uma comunicação razoável, amistosa, com a sociedade, os cidadãos entenderam rapidamente o porquê dessa medida. Entenderam que ficar em casa não era uma garantia individualista, mas coletiva. Entenderam que, beneficiando o coletivo, cada um poderia beneficiar a si mesmo. A razão era elementar: alguém que entrasse em quarentena não tinha garantia de ficar livre do vírus, mas tinha a garantia de que não serviria de vetor do vírus para os outros. Em outras palavras, um cidadão, sozinho, mesmo que disciplinado, não teria certeza de escapar da contaminação (a menos que se refugiasse numa bolha hermeticamente lacrada, sem contato algum com o mundo exterior, o que é virtualmente impraticável), mas, visto como uma solução não individual, mas coletiva, social, o isolamento alcançaria, como alcançou em várias cidades do mundo, um bom nível de eficácia.

O sentido ético dessa maneira de combate à pandemia nos convidava a superar o individualismo em favor do coletivismo. Uma lição e tanto. Tratava-se de assimilar o aprendizado de que a única forma de se deter o alastramento do mal - tornando-o mais lento e, consequentemente, mais controlável - era cuidar do outro antes de cuidar de si: eu não tenho meio de me imunizar contra a doença, mas eu tenho meios de evitar que o meu trânsito pela cidade contamine outras pessoas. E foi assim, com esse compromisso voluntário, que implicava assumir limitações individuais, que as comunidades ganharam alguma proteção. Foi um belo ensinamento ético: cuidar do outro antes para só depois, como consequência, obter um benefício para si. Se essa forma de prevenção sanitária pudesse ser lida como metáfora para a vida social, a mensagem até que seria animadora: a gente só fica bem quando se mobiliza para que os outros fiquem bem. Mas será que só essa metáfora nos autorizaria a ter uma expectativa positiva em relação ao futuro ${ }^{4}$ Será que o convívio humano melhoraria com a peste?

Não. A resposta é não. Durante aqueles dias estranhos já dava para saber que não, por maior que fosse a nossa torcida por um futuro venturoso. Mesmo no curso da pandemia, outros sinais, muitos outros, não encorajavam o otimismo. Ainda submetidos às regras do isolamento, já antevíamos que as resultantes 
do trauma sanitário da Covid-19 assumiriam semblantes distintos em diferentes regiões do globo. Talvez em um ou outro lugar as coisas evoluíssem bem, mas não dava para acreditar que viria a bonança e que a civilização sairia amadurecida disso tudo. As inquietações se impunham.

Por baixo das falas edificantes - muitas das quais todos nos apressaríamos a subscrever, pois reconhecemos ali, expressos, anseios e projetos legítimos -, fumegava um magma de indicações opostas. Flagrantes fugidios desses sinais se traíam, como sintomas, nos clarões hipnóticos da Indústria do Imaginário, a indústria que resulta da fusão de todos os complexos fabris do entretenimento, onde pulsam a publicidade, os shows jornalísticos e as demais usinas da representação instaladas nos conglomerados globais que hoje monopolizam a extração de olhar e sua monetização como um novelo em torno do planeta. ${ }^{5}$ Ainda referenciados, em parte, nas leis do Espetáculo (Debord, 1997) - ainda vigentes, apesar de mal lidas -, os clarões da Indústria do Imaginário não iluminam, ofuscam. Não obstante, se conseguimos ver através deles, detectamos as pistas de seus vórtices obscurantistas. Durante a pandemia, essas pistas apontavam as piores crueldades.

Nada de otimismo se poderia tirar dessas pistas. Nas limalhas incandescentes aspergidas como lixo pelos holofotes da Indústria do Imaginário, pressentíamos que, em lugar de milionários convertidos ao desapego e à humildade franciscana, já se avizinhavam sobrecargas de humilhação para os mais pobres; em vez de lemas de respeito à natureza, que se amontoavam no acostamento das narrativas, assomavam políticas não declaradas de devastação das matas; em detrimento dos programas proclamados de combate à desigualdade, o abandono dos vulneráveis.

Em abril de 2020, os piores presságios se desenhavam em miasmas no céu límpido paulistano, desobrigado de abrigar a poluição dos automóveis. $\mathrm{O}$ céu físico, em sua cristalinidade suspeita, emulava as telas eletrônicas nas quais a ganância exercia o monopólio sobre os sentidos da palavra solidariedade. Como sabemos, no capitalismo contemporâneo, onde a imagem da mercadoria encerra o valor prevalente da mercadoria, cada palavra cobra royalties e cada uma delas se presta à grilagem econômica (a linguagem é território em disputa nas novas relações de propriedade, pois o capitalismo dos nossos dias fabrica signos e só subsidiariamente fabrica objetos corpóreos).

Em plena pandemia, a fabricação de signos e de imagens seguia em velocidade máxima. O capital, o próprio, corria para se apresentar como arauto e dono do amor cristão entre os seres humanos. As maiores casas bancárias do Brasil desfiavam elogios plásticos a caridades cinematográficas em campanhas publicitárias massivas.

Tamanha overdose de imaginário teria sido irônica se não tivesse sido pútrida. O telespectador que tivesse um endereço em que se confinar via os anúncios demagógicos de bancos nos intervalos comerciais dos noticiários. $\mathrm{O}$ marketing financista chegou ao ponto de, numa peça assinada pelos três maio- 
res bancos privados da praça, prometer fundos para os pequenos empresários sem-fundo. ${ }^{6}$ (Os fundos faltariam, o que era o de menos.) Daí para a frente, a subliteratura com finalidades lucrativas e lacrimais só fez piorar. Um dos três conglomerados bancários se saiu com a ideia de doar um bilhão de reais para combater a pandemia, o que lhe rendeu, antes da vacina, mais um tsunami de anúncios televisivos em prol de si. $^{7} \mathrm{O}$ ideal da partilha comunitária, antes um bom sentimento difuso, instintivo, natural, sem proprietário privado, antes um elo comunitário, agora se desfigurava no espetáculo aflorado das entranhas encarvoadas da mais sólida concentração de capital.

Enquanto isso, as curvas da doença apontavam para o alto, para o Sol a pino, em progressões paroxísticas rumo ao infinito, de tal maneira que o fake - a propaganda piedosa dos cifrões - acabaria de braços dados com o mórbido - o desfile de féretros que começava a abrir sua temporada nos telejornais -, num baião de dois digital. Aí as telas eletrônicas recrutaram os cemitérios como espaço cenográfico: cemitérios revirados pelo avesso, em 'terraradas' revoltas. Numerosos jazigos públicos, perfilados como planilha de Excel, carimbavam o solo sem calçamento das necrópoles. Sobre o chão escalavrado, casulinhos matriciais, alinhados em marrom escuro, ofereciam covas rasas para a plateia. $\mathrm{O}$ show não podia parar. Em maio, retroescavadeiras entraram em cena para cobrir com nacos de barro os caixões anônimos que chegavam em carrocerias. Não, aquelas cenas não eram ritos de sepultamentos, eram pavimentações em que motoniveladoras amarelas aplainavam o terreno em cima de dúzias de urnas mortuárias sem flores, sem pranto, sem ninguém. Coveiros tratorizados.

Com olhos vítreos, a classe média trancafiada vislumbrava o fim de todos os cerimoniais fúnebres. Se a morte já não merecia cerimônias, era porque a vida já não valia nada, ou quase nada. Os telespectadores não eram chamados a prantear seus mortos. Não eram chamados a velá-los. Só lhes cabia olhar e esperar. Suas frágeis vaidades de classe média evaporavam sob a ação abrasiva e abrasadora das duas forças do imaginário industrial enlaçadas no baião de dois: o fake publicitário e o mórbido jornalístico. A morbidez das notícias deixava o fake mais fake. De outro lado, o fake da publicidade bancária tornava o mórbido ainda mais sádico, assim como tornava o otimismo uma funesta miragem.

O melodrama das campanhas publicitárias dos senhores do dinheiro tinha agora o jeitão de um sorriso de photoshop. A comiseração capitalista não convencia, embora abundasse. Impossível crer que a banca acreditasse no que vendia. Àquela altura, já estava nítido o estrago que viria. Os gerentes do capital sabiam que a recuperação do Brasil não seria rápida, e sabiam que o país sairia enfraquecido dessa história. ${ }^{8}$

Os bancos não eram - não são e nunca foram - um setor desinformado ou ingênuo. Por isso, diante daquela marquetagem financista festejando criancinhas ${ }^{9}$ e sentimentalismos, o mais plausível era supor que, sob o manto de resgatar seres humanos da indigência, a meta fosse livrar o sistema inteiro da 
inadimplência generalizada e da subsequente liquefação fatal. Era preciso salvar a confiança (essa moeda) no íntimo dos tomadores de crédito (essa outra moeda). Bancos não se movem para salvar vidas, movem-se para salvar a si mesmos, ainda que, para tanto, tenham que chegar ao desplante de salvar vidas.

A massa compacta dos anúncios bancários tentava inocular um antídoto contra o pavor, mas os olhos da classe média, inclusive aquela que se imaginava alta, não comprava o ilusionismo. A subjetividade dos que dependiam da sensação de privilégio para sentir autoconfiança tinha se quebrado. Suas veleidades não estavam mais de mãos dadas com a empáfia. O que havia nos olhos aturdidos diante das telas era agora uma "melancolia de classe", quer dizer, um desamparo afetivo da classe que só é classe quando se identifica em laços libidinais com os caprichos da classe dominante. Ressentimento de uma classe sem classe.

Esse estado de desânimo se instaurou de uma semana para outra. Foi rápido. Primeiro, a classe média das regalias fantasiosas, ainda se acreditando a própria encarnação da aristocracia, dedicou-se a entupir de pacotes de papel higiênico o armário da garagem. Gostou disso, viu nisso um esporte competitivo. Depois, vieram as gincanas por barris de álcool em gel e por máscaras cirúrgicas. Nas lives de Instagram, celebridades posavam com máscaras de grife. Irrompeu ainda a histeria em torno de fármacos de nomes empedrados, como hidroxicloroquina. Mas, passadas as febres consumistas, e tudo em fast forward, restou o deserto das vaidades caídas. Órfãs. A essa altura, a bondade obscena virava trunfo imagético da usura oficial e a peste avançava nas periferias, jantando corpos aos caminhões.

A autoestima dos remediados subalternos se desfez em tempestades de areia. De um mês para o outro, os que já não tinham como se jactar da bacaneza aprenderam que não importavam um níquel, que não passavam de anônimos nas cortes em que se presumiam convidados de honra. Descobriram-se um lumpesinato cacarejante, demitido das ilusões. A pandemia lhes matou os ares de fidalguia falsificada, e o fez com tanta torpeza que não mais precisava lhes matar o organismo. No vácuo do medo, o ódio cresceu.

Estas linhas, estas mesmas que seus olhos agora percorrem sem maior interesse, foram escritas em fins de maio sem maior conviç̧ão. Tão sem conviç̧ão que tiveram de ser construídas, desconstruídas e reconstruídas muitas vezes. Mal se aprumavam e já se esvaneciam, como a autoestima dos remediados. $\mathrm{Na}$ template subjacente à alvura impedante da tela, as letras cerravam sua fileira, marchando adiante, para logo retroceder. As frases vinham e em seguida eram apagadas pela tecla do backspace, esse marcador histórico mais imperioso que qualquer zeitgeist. A um palmo do nariz do escrevinhador, o cursor ia, ao ritmo dos caracteres em fila, e depois voltava, sob a sanha do backspace desbastador. Nas idas, preposições e formas verbais se comprimiam em formações instáveis. Um par de segundos depois, tinham sido deletadas. Cada linha secundada por uma supressão de linha. Agora vai. Agora não vai mais. Outra linha e mais outra 
supressão. Sentenças se equilibravam e se desmilinguiam. No vazio deixado pelo desmonte, remodelagens do mesmo timbre caminhavam trôpegas.

Foi um custo. Cada sílaba era assentada como um tijolo, um após outro. Tijolos pesados, cada um deles, e que depois sumiam no ar como bolhas de sabão. Tijolos, quase todos, defeituosos. Para empilhá-los, os dedos retesados, no seu sapateado sem graça, tamborilaram sem norte. Hesitações penosas e voláteis em ritmo de vai-não-vai.

Estas palavras nasceram em meio a um cosmos sangrento ou, pior, exangue, de tal sorte que agora é tarde. O impulso "deletante", afinal, não venceu a pulsão diletante. Prevaleceu, como se nota, o diletantismo pessimista. E para quê? Para quem? Para que estas histórias? Aliás, olhemos para longe: para que a História, aquela com $\mathrm{H}$ maiúsculo? Num tempo em que as condutas performáticas dos líderes populistas se orientam pela desorientação caótica daquilo que excita as redes sociais, de que valerá a memória? De que vale a coerência? De que vale a lógica entre um ato e outro? De que valeriam então estas linhas? E, repita-se, de que vale a História? Este é o ponto. Este é o ponto de interrogação.

De todo modo, enquanto estas linhas iam e vinham, estas aqui, foi ocioso observar uma vez mais que, na nossa língua portuguesa e, de resto, como no grego, como no latim, a gente escreve para a direita e desescreve para a esquerda. (Será assim com todas as línguas indo-europeias?) Quando batucava suas sílabas fracas, o escrevinhador acompanhava o cursor a se mover para a direita. Era um ser solitário puxando um arado em canteiro seco. Quando as dizimava dá-lhe, backspace -, sentia alívio ao ver o mesmo cursor retornando como roçadeira, desmatando ideias rumo à margem esquerda. Naqueles dias pandêmicos, dias e noites que ainda persistem, desescrever teria sido mais sábio. A margem esquerda quer de nós a desescrita, mas a direita, que prefere a produtividade, exige o texto pronto. Que assim seja. Como campo gravitacional, a margem direita se sobrepôs à outra.

Nos avanços e recuos inúteis do digitador que se via como prestidigitador, um vaticínio usurpou o moto autoral do que ficou: a peste que sobre nós choveu vai nos legar desolação e leveza. Desolação por que é isso aí. Leveza porque, de resto, já não importa. Sairemos disso menores e mais dispensáveis do que entramos. Leves como uma gotícula de saliva no ar. Fungíveis à exaustão. No final - se é que final haverá - ficarão de pé o dinheiro, só não se sabe em que moeda, e a violência, só não se sabe em que grau de explicitude. Os órfãos das vaidades caídas vão agora se apegar à violência com os seus dentes clareados. Serão mortíferos, muito embora irrelevantes. Não apenas eles, aliás. Doravante, a humanidade se reconhecerá irrelevante, e tal reconhecimento não virá como tragédia, mas como banalidade estéril.

Antes de decifrar a irrelevância, ocupemo-nos da mortalidade. Vem do poeta e ensaísta francês Paul Valéry o alerta de que as civilizações são mortais. Não 
que, no celebrado texto de 1919, Valéry tenha nos contado alguma novidade. Ele apenas avisou, e logo na primeira frase, o que já era sabido: "Nós, civilizações, sabemos agora que somos mortais". ${ }^{10}$

E por que não saberíamos? Civilizações, pífias ou exuberantes, morreram copiosamente, inclusive aquelas que foram abortadas, as que se deixaram deletar antes de abrir parágrafo. Morreram civilizações em tal abundância que, há um século, Valery admitia: "Sentimos que uma civilização tem a mesma fragilidade que uma vida". ${ }^{11}$ Traduzamos: a mesma fragilidade de um cão de rua, de uma cascavel no agreste, de um sapo equatorial ou de um banqueiro hibernado na fazenda.

A consciência da mortalidade das civilizações foi tão assimilada que já se gastou, mas antes que se lance contra a frase de Valéry o rótulo de lugar-comum, algo que pouco acrescentaria, convém lembrar que essa ideia já foi traumática, uma vez que houve, antes, os que acreditavam que a civilização, esta na qual estamos embarcados, cruzaria os portais do tempo, incólume feito um jorro de neutrinos. Hoje, os que assim acreditavam estão mortos. Na pandemia de 2020, a finitude teórica da civilização não passa de platitude. Em seu lugar brotaram dizeres mais impactantes, ou sensacionalistas, como aqueles que - pour épater le petit bourgeois - anunciam a morte total da humanidade.

Está na moda falar do desaparecimento da espécie humana. A nossa extinção frequenta como arroz de festa ou salgadinho de velório uma vastidão de escritos, acadêmicos ou não. Por vezes, em meio ao barulho em torno do aquecimento global, a tese eclode em palavreados mais ou menos alarmistas. ${ }^{12}$ Fala-se, e fala-se sem a menor cerimônia, não apenas no desaparecimento do homo sapiens, mas na calcinação de toda forma de vida no planeta. Quando não tanto, fala-se no encerramento da vida inteligente (o autoelogio vai de cambulhada) e, nos prognósticos mais conservadores, fala-se na extinção de parte considerável dos biomas da Terra. Sem drama.

Vivemos uma era em que lidamos com naturalidade com a morte de tudo. Civilizações morrem, espécies somem, ecossistemas viram pó. Nada disso incomoda. Só o que talvez seja um problema é que, no ambiente distópico das relações de produção em que ingressamos, com a uberização de tudo, até do amor verdadeiro, o humano perde peso e centralidade. Se vamos mesmo desaparecer, parece que vamos desaparecer sem brilho. Isto, isto sim, talvez seja um problema.

Mais do que desempregadas, as grandes massas transnacionais, migrantes ou não, miseráveis ou não, proletarizadas ou subproletarizadas, não têm nenhuma perspectiva de se integrar ao processo produtivo, o que se constitui num tópico intrincado para cenários de médio e de longo prazos. O que fazer com isso? Distribuir renda mínima para que as gerações condenadas à inutilidade não morram de fome em aterros sanitários? Será que basta?

Não são apenas os corpos e os músculos de multidões que perdem função também a imaginação humana se escanteou. Ainda mais humilhante do que o desemprego perpétuo das maiorias é o modo como a Inteligência Artificial e as 
máquinas capazes de "aprender" vão deslocando e desativando o espírito - o espírito, aqui, no sentido exato que lhe dava Paul Valéry.

Que espírito é esse? Não se trata do espírito cartesiano, o intelecto em trabalho, aquilo que leva o filósofo a dizer, na primeira pessoa, que é "apenas uma coisa que pensa". Tampouco se trata do espírito hegeliano, que, em sua manifestação mais alta, encarnaria a razão superior que regeria a natureza e os seres racionais (pois "o real é racional"). Trata-se de um espírito que não se despe inteiramente dos marcos que o antecedem, mas ousa transbordá-los.

Entre nós, quem melhor nos ensina sobre o espírito em Paul Valéry é o filósofo Adauto Novaes. Em 2013, no magnífico ensaio "Mundos possíveis", com que introduziu um dos seus ciclos de palestras - ciclo que levava um título, por assim dizer, desescrevedor, O futuro não é mais o que era-, Adauto anotou com notável concisão que, para Valéry, o espírito é "potência em transformação". Uma das raízes dessa proposição remontaria a Santo Agostinho, para quem o espírito poderia ser entendido, sempre de acordo com Adauto, como "o trabalho permanente da inteligência como potência de transformação". Essa apreensão de um sentido talvez poético do "espírito" nos leva a divisar uma vibração pensante que, sendo matéria, existe como potência dotada de imaginação que, com liberdade incondicional, age sobre o mundo para transformá-lo. O espírito humano é aquele que inventa o humano que o inventou.

E assim vai inventando e (se) transformando, até que bate num limite (limite que tem sido o tema essencial na obra recente de Adauto Novaes). No nosso tempo, o espírito teria trombado contra esse limite e, consequentemente, estaria em xeque, ameaçado de morte, ou mesmo ferido de morte. Mas ferido por quem? Ameaçado por quem? Ora, responderá Valéry, pelo próprio espírito. Sigamos ainda com Adauto Novaes.

Acontece, diz o poeta [Valéry, no ensaio "Notre destin et les lettres"], que o espírito - esta potência de transformação - subverteu o mundo de tal maneira que acabou por voltar-se contra o próprio espírito: um mundo transformado pelo espírito, no qual as invenções aceleradas nascem e modificam em pouco tempo os costumes, a política, a ética, as mentalidades, a vida social, enfim, o mundo das transformações técnicas e científicas "não oferece mais ao espírito as mesmas perspectivas e as mesmas direções de antes e impõe a ele problemas inteiramente novos, inúmeros enigmas". (Novaes, 2013, p.1)

É assim que, na senda filosófica, desvenda-se a doída sina do espírito que esvazia o espírito. Adauto reage: "O que acontece com esta potência de transformação [o espírito] quando a modernidade procura transformar o espírito em coisa supérflua, como afirma ainda Valéry?” (ibidem).

Incrível essa expressão, "coisa supérflua". Concedamos que a visão do poeta francês nos chega com um século de defasagem. Valéry presenciou as convulsões, não apenas tecnológicas, mas políticas e estéticas, numa época marcada 
pela Primeira Guerra Mundial. Por certo, viu além daquilo que testemunhou, mas o tempo em que ele disse o que disse parece ir longe agora. Desde então, os solavancos e as rupturas cresceram exponencialmente em extensão e aceleração. Em certas ocasiões dos nossos dias, a sensação teórica que nos envolve é a de que o velho espírito, o mesmo que foi declarado "coisa supérflua" há cem anos, não passa agora de um acessório.

Uma Poliana poderá alegar que estamos exagerando. Afinal, diria a Poliana, os algoritmos ultrassecretos e opacos, mesmo eles, os algoritmos que governam impassíveis o fluxo de opiniões nas redes sociais (uma delas com mais de três bilhões de usuários ativos no mundo ${ }^{13}$ ), não passam de prodígios do espírito humano. Logo, são criações humanas. A Poliana poderá ainda arguir que os conglomerados que monopolizam, em escala global, a Indústria do Imaginário e as ferramentas extratoras de olhar, constituem uma obra do espírito. Assim, é o espírito que ainda está no centro.

Será mesmo? Haja otimismo. O que dizer quando algoritmos e os conglomerados nos quais se escondem confinam a espontaneidade criativa das gentes de carne e osso? Ao engendrar tais engenhos - a Inteligência Artificial, o big data, os algoritmos e os conglomerados monopolistas da tecnologia e da extração de olhar-, o espírito fez deles os algozes do próprio espírito (o seu monstro frankesteiniano, para nos valermos aqui de uma metáfora, também ela, velha de um século). Naquilo que tinha de mais humano, o espírito assim nomeado por Paul Valéry e por Adauto Novaes perdeu lugar, foi reduzido a "coisa supérflua" e, pobre dele, até perdeu o emprego. Como as grandes massas, vaga sem ocupação. A Inteligência Artificial acarreta a aposentadoria compulsória do espírito. Quando muito, o espírito conseguiu uma vaga decorativa e mal remunerada num board consultivo da Amazon ou do Facebook.

Ou da IBM. Faz pouco tempo, a gigante da tecnologia adotou um slogan publicitário que diz tudo: "A inteligência pronta para trabalhar". Esse slogan soa em toda parte, como um mantra obsessivo da IBM. Mas o que será que isso quer dizer? O que tinham na cabeça - cabeça sem espírito - o publicitário que inventou esse slogan e o executivo que o aprovou? Por mais que pensar, hoje, seja uma apostasia inaceitável, pensemos um pouco. Que tipo de elos semânticos foram ativados pela sintetização desse bordão? De que forma se pode entender o significado da palavra "inteligência" aí? O que se tem de seguro é que "inteligência", no contexto do slogan, é um ente que "trabalha". Nos textos promocionais da IBM, os textos que dão sustentação ao slogan, enfatiza-se que os equipamentos e os serviços da marca resolvem prestimosamente os impasses enfrentados pelos os clientes. A “inteligência”, portanto, tem uma aplicação direta em empresas produtivas, em organizações que precisam de soluções para funcionar melhor. Estamos falando, então, de uma "inteligência" que dá resultados e gera lucros, uma vez que, além de ser inteligente, e além de ser, também, artificial (a empresa investe em estudos e projetos ligados ao conceito que tem de "inteligência 
artificial"), a solução vendida pela empresa trabalha muito bem, trabalha que é uma beleza. Logo, estamos falando de uma "inteligência" bem formatada, bem programada, bem adestrada e rentável.

O substantivo "inteligência" ganha, subsequentemente, uma forma nova de apropriação nessa era em que o capital se apropria de significantes e finca suas cercas de arame farpado no chão da linguagem. O substantivo "inteligência" passa a querer dizer aquilo que a IBM reitera o tempo todo que ele quer dizer. No vocabulário da IBM, que se estende sobre o vocabulário comum, a "inteligência" se dissocia do seu sentido crítico, posto que "inteligência", nesse vocabulário, em vez de crítica, é obediente, solícita, prestativa, diligente. A “inteligência", agora, encerra em si a vantagem competitiva da jornada ininterrupta de "trabalho". O fator mais disruptivo de tudo isso (as chamadas big techs se aprazem em tagarelar sobre cenários "disruptivos", assim como falam em "inicializar" e em "descontinuar") é que, agora, com a tecnologia, nada menos que a "inteligência" poderia finalmente estar "pronta" para "trabalhar" na direção que o cliente escolher. Note-se, agora, o milagre do silício: não é mais a inteligência (o espírito pensante e imaginativo) que desenha o lugar do trabalho, mas a exploração do trabalho que dá emprego e orientação à "inteligência". A "inteligência" se subordina a um critério que ela mesma, "inteligência", desconhece, para "trabalhar" em algo cujos efeitos não domina. Funda-se, com isso, o híbrido fabuloso da "inteligência" alienada.

É isso ou nada. Se não for assim, a inteligência não servirá para nada. A propósito, falando em entes úteis, para que servirá agora a poesia? Terá de ser "posta para trabalhar" ela também? E será que já não foi posta para trabalhar, para além do espírito? O que sucederá com a Filosofia? Terá observado o improvável leitor que hoje estão em voga os projetos de universidades sem Filosofia e sem artes? Notou que são projetos de universidade sem espírito? E o que ocorrerá com a contemplação, esse estado do espírito descrito por Aristóteles como o mais elevado grau da felicidade? Tudo isso passará a ser coisa supérflua? Ninguém precisa de mais elementos, além dos já dados, para responder a esse tipo de interrogação. De um jeito ou de outro, eis que o ex-atributo do espírito chamado um dia de inteligência (ou de prudência, nas virtudes gregas) cai em desuso. A não ser, bem entendido, que "seja estar pronta para trabalhar". A menos que consiga um emprego na IBM.

E olhe que não foi sem aviso. Nó século XIX, Karl Marx já tinha rabiscado alguma coisa sobre o "mundo sem espírito". Não foi sem aviso mesmo. Mais de um século depois, escancarou-se a fissura entre o espírito e a supermodernidade maquínica que, embora arquitetada em parte pela imaginação do espírito, anda sem o espírito e prefere andar assim. O retrato hiper-realista do novo mundo sem espírito - a expressão "mundo pós-espírito", que seria infeliz e de mau gosto, está a um milímetro de ser patenteada - são as covas em formação militar nos cemitérios de retroescavadeiras. A pandemia antecipou o trauma anunciado. 
A pandemia demonstrou, com os coveiros motorizados e com os bancos de fiduciária empatia, que o espírito que fazia dos homens uma humanidade é economicamente supérfluo, assim como comprovou que a humanidade, ela mesma, é um estado irrelevante da matéria.

Não contam, nem o espírito humano nem a humanidade inteira. A humanidade já não é baliza. Não precede. E também não é fim. Aquela que, para Kant, deveria ser sempre o fim, nunca o meio, viu-se reduzida a um aparelho de obsolescência programada. Aquela que emprestava sacralidade a qualquer ideia que a invocasse, mal se segura como substantivo coletivo. A humanidade está para os humanos assim como a alcateia está para os lobos. Interessante, no presente contexto linguístico, ver cientistas e políticos falando em "imunidade de rebanho". Interessante: desumano rebanho humano. De um certo ponto de vista, a nossa civilização vem morrendo pelas estribeiras à medida que se embrutece e triunfa.

No mês de abril, correu a notícia de que, em todo o mundo, 4,5 bilhões de pessoas tinham entrado em alguma forma de confinamento. ${ }^{14} \mathrm{O}$ dado impressionava por sua magnitude: nada menos do que seis em cada dez seres humanos sobre a Terra viviam em regime de quarentena, trancados em casa, sem ir ao trabalho, sem ir à escola, sem ir ao bar ou ao cinema. Em grandes cidades, apenas em circunstâncias excepcionais as autoridades permitiam que alguém saísse de casa: o salvo-conduto valia para ir comprar comida ou remédio ou para prestar serviços indispensáveis, como no caso dos médicos, enfermeiros, policiais, lixeiros, caminhoneiros, jornalistas. Em decorrência de sua magnitude colossal, o dado impressionava também pelo que revelava a respeito das engrenagens produtivas do capitalismo atual. Mesmo numa circunstância em que 4,5 bilhões de terráqueos sofriam restrições severas, e nada usuais, para se deslocar, a produção de mercadorias, o trânsito do dinheiro e os movimentos do mercado não feneceram. Mesmo com uma absurda escassez de gente, a economia seguiu.

Com o advento da Covid-19, descobriu-se que a presença física de seres humanos, a não ser em funções singulares, atípicas, podia ser dispensada, sem prejuízo do vigor do sistema. Houve mesmo alguns eufóricos. Em toda parte, comentaristas, cronistas e os inevitáveis especialistas habitués dos meios de comunicação, todos em regime de confinamento, teceram loas e mais loas (a distância, lógico) às maravilhas tecnológicas que inauguraram a modalidade telemática do "trabalho remoto". Uma vez mais, a técnica salvava o capitalismo. Uma vez mais, festejos verbais assinalavam que a técnica salvava a economia. No bojo do vozerio, o significado dos termos "remoto" e "a distância" mudou. O palavrão "presencial” ganhou outra dimensão, sobretudo porque as coisas humanas deixaram de ser feitas, com o perdão da palavrada bruta, "presencialmente". Nunca se fez tanto amor "virtual" como nos tempos da Covid-19. Não são necessárias pesquisas empíricas para saber que foi assim. 
Na pandemia, o capitalismo era outro. Ele, que se desenvolveu comprando "força de trabalho" dos corpos humanos, também ele, aderira à moda de se reinventar. E foi fácil, pois reinventado já estava.

Antes, quando comprava "força de trabalho", a linha de produção era movida a sangue. A Revolução Industrial modificou a planta de fábrica, por certo, mas, ainda no século XX, ou em três quartos do século XX, as relações de produção não poderiam prescindir da ação física do trabalhador sobre a coisa fabricada. A exploração se dava in loco, de corpo presente. Quando a pandemia chegou, já não é assim. A automação do valor agregado (valor-a-mais sobre valor-a-mais) requisita menos do corpo e mais da alma. Por isso, pôde se dar ao luxo de explodir as jornadas de trabalho medidas em horas contínuas. A produção desse capitalismo reinventado explora a imaginação domesticada, a inteligência alienada, o espírito decaído, e nada disso se mede no relógio.

O capital já não explora o suor, mas o engajamento pulsional. Aprendeu a explorar o desejo tanto na produção como no consumo, assim como aprendeu a explorar o olhar como trabalho. No capitalismo que fabrica imagem, signo e valor de gozo (Bucci, 2019), o humano migra dos turnos laborais de oito horas para a conexão online que não se apaga durante as 24 horas do dia. Assim, enquanto 4,5 bilhões de seres humanos praticavam o novo esporte passivo da quarentena, o capitalismo cortou mais alguns laços de dependência que mantinha em relação à humanidade. Naqueles dias, os professores da USP, com seu trabalho dito não essencial oferecido remotamente, adstrito a uma voluntariosa prisão domiciliar, sentiam que trabalhavam ainda mais do que antes. Com efeito, trabalhavam mais, de fato.

Essa ordem de transformações sobrepostas, que reconfiguraram o capital, repaginaram a cultura. Em lugar dos encontros chamados de "presenciais", emergiram outros planos de aproximações. Avatares substituíram corpos, as presenças se renderam às telepresenças, ${ }^{15}$ os espaços públicos se transmutaram em telespaço público - onde é possível estar em diversos espaços ao mesmo tempo e onde é possível concentrar, materialmente, espaços distintos num só. A comunicação social se deslocou da Instância da Palavra Impressa para a Instância da Imagem ao Vivo (Bucci, 2009a), que alcançou complexidades múltiplas com as tecnologias digitais. O sujeito foi alçado a planos paradoxais de existência para além do corpo - age no mundo sem ter que pisar sobre o mundo. $\mathrm{O}$ dinheiro viaja na velocidade da luz. O olhar viaja na velocidade da luz. O desejo também. O discurso. Quanto ao corpo, este jaz em quarentena.

Nas planilhas do capitalismo, a maioria dos habitantes do planeta, nesta geração e, principalmente, nas próximas, recebe na testa uma rubrica menos digna do que a de "exército de reserva". Vidas humanas não apenas não geram riqueza, como podem importunar a conta. Entulho. Detritos industriais. Irrelevância existencial. Irrelevância material. Irrelevância metafísica. $\mathrm{O}$ humano ainda é um instrumento, mas cada vez mais descartável (Bucci, 2009b). 
Pela primeira vez na história, vemos um governante dar de ombros para a morte de sua gente. Indagam-no a respeito dos óbitos causados pela peste, dezenas de milhares de falecimentos, e ele responde com ar de pouco caso: " $\mathrm{E}$ daí?”. ${ }^{16}$ Não que o fascismo desfigurado, anacrônico e adulterado que aí está, um fascismo ainda mais abjeto que o original, seja uma das causas da irrelevância da humanidade. É pior do que isso. O mais provável é que o fascismo rebaixado que nos abduz seja um reles sintoma, apenas um sintoma a mais. $\mathrm{O}$ que não impede você, nem a ninguém, de se deixar enlevar pelo otimismo.

\section{Notas}

1 Um dos jornalistas que melhor detectararam e documentaram essa tendência foi Alexandre Mansur, em artigo para a revista Exame, em 1 de abril de 2020: "Haverá um resgate de estilos de vida simples, mais focados nas relações humanas, na saúde e na felicidade, e menos na acumulação de bens tidos como supérfluos” (Mansur, 2020).

2 Um excelente panorama dessa possível tendência aparece no artigo, bem documentado e fundamentado, de Francisco de Assis Esteves, vice-diretor do Instituto de Biodiversidade de Sustentabilidade (Nupem), da UFRJ, do qual foi fundador. Ver Esteves (2020).

$3 \mathrm{O}$ pesquisador Yasha Mounk foi um dos que verbalizaram essa possibilidade. Ver a entrevista concedida por ele ao site em português da BBC News (Idoeta, 2020).

4 Ver artigo "Por que, em vez da doença, eu prefiro a cura como metáfora" (Buci, 2020).

5 Sobre os conceitos de "Indústria do Imaginário" e "extração de olhar", ver Bucci (2019).

6 Bradesco, Itaú e Santander, juntos pela sua empresa. Disponível em: <https://www. youtube.com/watch?v=w42DrqU8aI4>. Acesso em: 19 abr. 2020.

7 Disponível em: <https://www.youtube.com/watch?v=BSRfkGLTxN8>. Acesso em: 19 abr. 2020.

8 Estrago que, num artigo assinado pelo ex-embaixador Rubens Barbosa, presidente do Conselho Superior de Comércio Exterior da Fiesp, foi descrito em termos duros: "Análises e estudos das principais organizações internacionais indicam que a pandemia pode estender-se por um período maior que o antecipado. A vacina contra a covid-19 promete tardar para ser comercializada. A recessão global vai ser profunda e demorada. As consequências sobre a economia e o comércio internacional poderão ser devastadoras, com grave queda do crescimento e do desemprego global. A recuperação do Brasil não vai ser rápida, nem o País sairá mais forte, como alguns anunciam” (Barbosa, 2020).

9 A pretexto de homenagear os médicos, o Bradesco veiculou uma peça publicitária em que crianças atuam, fazendo de conta que são médicos examinando com estetoscópios seus bonecos de brinquedo. Disponível em: <https://acontecendoaqui.com.br/ propaganda/ao-som-de-elis-regina-almapbbdo-apresenta-campanha-do-bradesco-saude>. Acesso em: 27 maio 2020.

10 "Nous autres, civilisations, nous savons maintenant que nous sommes mortelles". Usa-se aqui a edição eletrônica disponível em PDF no site Ouvres Ouvertes (Valéry, 2020). Original de 1924. 
11 "Nous sentons qu'une civilisation a la même fragilité qu'une vie" (Valéry, 2020). Original de 1924.

12 Um exaustivo levantamento da ocorrência dos discursos que anunciam "a extinção humana a curto prazo" (como na expressão de Guy McPherson), pode ser visto em Wallace-Wells (2019). Veja-se, em especial, o capítulo "Ética no fim do mundo".

13 O Facebook chegou a 2020 com 2,5 bilhões de usuários no mundo. Disponível em: <https://www.oficinadanet.com.br/post/16064-quais-sao-as-dez-maiores-redes-sociais>. Acesso em: 28 maio 2020.

$14 O$ Globo. Coronavírus deixa 4,5 bilhões de pessoas confinadas no mundo. 17.4.2020. Disponível em: <https://oglobo.globo.com/mundo/coronavirus-deixa-45-bilhoes-de-pessoas-confinadas-no-mundo-24378350>. Acesso em: 27 maio 2020.

15 A expressão é de Paul Virilio (1995, p.131).

16 "O presidente Jair Bolsonaro afirmou nesta terça-feira (28/04/2020) que lamenta, mas não tem o que fazer em relação ao novo recorde de mortes registradas em 24 horas, com 474 óbitos, ultrapassando a China no número total de óbitos pelo novo coronavírus. 'E daí? Lamento. Quer que eu faça o quê? Eu sou Messias, mas não faço milagre', afirmou ao ser questionado sobre os números” (Chaib; Carvalho, 2020).

\section{Referências}

AO SOM de Elis Regina, AlmapBBDO apresenta campanha do Bradesco Saúde. Acontecendo Aqui. Florianópolis, 18 maio 2020. Disponível em <https://acontecendoaqui. com.br/propaganda/ao-som-de-elis-regina-almapbbdo-apresenta-campanha-do-bradesco-saude>. Acesso em: 27 maio 2020.

BARbOSA, R. Bom senso acima de tudo. O Estado de S. Paulo. São Paulo, 26 maio 2020, p.A2. Disponível em: <https://opiniao.estadao.com.br/noticias/espaco-aberto,bom-senso-acima-de-tudo,70003314426>. Acesso em: 26 maio 2020.

BUCCI, E. Em torno da instância da imagem ao vivo. Revista Matrizes, São Paulo, ano 3, n.1, p.65-79, ago./dez. 2009a.

Aquilo de que o humano é instrumento descartável: sensações teóricas. In: NOVAES, A. (Org.) A condição humana: as aventuras do homem em tempos de mutações. Rio de Janeiro: Agir Editora Ltda.; São Paulo: Edições Sesc SP, 2009b. p. 375-94.

. Extrativismo do olhar, valor de gozo e palavras em refluxo. Revista Brasileira de Psicanálise, v.53, p.97-114, 2019.

Por que, em vez da doença, eu prefiro a cura como metáfora. O Estado de S. Paulo, São Paulo, 26 mar. 2020, p.A2. Disponível em: <https://opiniao.estadao. com.br/noticias/espaco-aberto,por-que-em-vez-da-doenca-eu-prefiro-a-cura-como-metafora,70003248211>. Acesso em: 26 maio 2020.

CHAIB, J.; CARVALHO, D. "E daí? Lamento, quer que eu faça o quê??", diz Bolsonaro sobre recorde de mortos por coronavírus. Folha de S.Paulo, São Paulo, 28 abr. 2020. Disponível em: <https://wwwl.folha.uol.com.br/equilibrioesaude/2020/04/e-dai-lamento-quer-que-eu-faca-o-que-diz-bolsonaro-sobre-recorde-de-mortos-por-coronavirus.shtml>. Acesso em: 19 maio 2020. 
DEBORD, G. Sociedade do espetáculo. Rio de Janeiro: Contraponto, 1997.

ESTEVES, F. de A. Coronavírus impõe guinada à sustentabilidade. Universidade Federal do Rio de Janeiro. Rio de Janeiro, 29 abr. 2020. Disponível em: <https://ufrj.br/ noticia/2020/04/29/coronavirus-impoe-guinada-rumo-sustentabilidade>. Acesso em: 25 maio 2020 .

IDOETA, P. A. Pandemia pode enfraquecer populismo nos EUA e no Brasil, diz pesquisador de democracias. BBC News Brasil, São Paulo, 12 abr. 2020. Disponível em: <https://www.bbc.com/portuguese/internacional-52100135>. Acesso em: 25 maio 2020.

ITAÚ. Conheça o todos pela saúde. Disponível em: <https://www.youtube.com/ watch?v=BSRfkGLTxN8>. Acesso em: 19 abr. 2020.

MANSUR, A. Oito megatendências para o mundo pós-coronavírus. Exame, São Paulo, $1^{o}$ abr. 2020. Disponível em: <https://exame.com/blog/ideias-renovaveis/oito-megatendencias-ecologicas-para-o-mundo-pos-coronavirus/>. Acesso em: 25 maio 2020.

NOVAES, A. Mundos possíveis. In: . (Org.) O futuro não é mais o que era. São Paulo: Edições Sesc SP, 2013. Disponível em: <https://artepensamento.com.br/item/ mundos-possiveis/?_sf_s=futuro+mais+era+adauto+val\%C3\%A9ry>. Acesso em: 25 mai. 2020.

O GLOBO e agências internacionais. Coronavírus deixa 4,5 bilhões de pessoas confinadas no mundo. O Globo. Rio de Janeiro, 17 abr. 2020. Disponível em: <https:// oglobo.globo.com/mundo/coronavirus-deixa-45-bilhoes-de-pessoas-confinadas-no-mundo-24378350>. Acesso em: 27 maio 2020.

SANTANDER. Brasil. Bradesco, Itaú e Santander, juntos pela sua empresa. Disponível em: <https://www.youtube.com/watch?v=w42DrqU8aI4>. Acesso em: 19 abr. 2020.

VALERY, P. La cirse de l'Esprit. Site Ouvres Ouvertes. Disponível em: <http://oeuvresouvertes.net/IMG/pdf/valery_crise.pdf>. Acesso em: 18 maio 2020.

VIRILIO, P. Imagem virtual mental e instrumental. In: PARENTE, A. (Org.) Imagem-Máquina: a era das tecnologias do virtual. Rio de Janeiro: Editora 34, 1995.

WALLACE-WELLS, D. A Terra inabitável. São Paulo: Cia. das Letras, 2019.

RESUMO - Num exame da cultura cotidana (em tempos da pandemia de Covid-19) através da análise de fragmentos da Indústria do Imaginário, o presente artigo capta sinais da desvalorização do conceito ético de humanidade, seja como um condensado de valores que envolvem solidariedade e empatia, seja como expressão máxima da espécie humana no tempo e no espaço. Nesse contexto, nota-se que, como apontou Paul Valéry (conforme a leitura de Adauto Novaes), “o espírito" se tornou "coisa supérflua”. Nota-se, ainda, o rebaixamento do que se entende por inteligência humana, num processo que reduz a humanidade teria se reduzido a um expediente instrumental (um meio), e até certo ponto des cartável, colonizada pelo capital. A pandemia, como um concentrado de eventos no plano da cultura, torna tudo isso visível.

PALAVRAS-CHAVE: Covid-19, Indústria do Imaginário, Espírito, Cultura, Instância da Imagem ao Vivo. 
ABSTRACT - By examining everyday culture (in times of the covid-19 pandemic) through the analysis of fragments of the Industry of the Imaginary, this article captures signs of the devaluation of the ethical concept of humanity, whether as a condensation of values that involve solidarity and empathy, or as the maximum expression of the human species in time and space. In this context, it should be noted that, as Paul Valéry pointed out (according to the reading by Adauto Novaes), "the spirit" became "superfluous." It should also be noted that the demeaning of what is understood as human intelligence, in a process that reduces humanity to an instrumental expedient (a means), to some extent disposable, colonized by capital. The pandemic, as a concentration of events at the cultural level, makes all of this visible.

KETWORDS: Covid-19, Industry of the Imaginary, Spirit, Culture, Live Image domain.

Eugênio Bucci é jornalista, graduado em Comunicação Social e em Direito pela Universidade de São Paulo, é doutor pela Escola de Comunicações e Artes da USP, onde atualmente é professor titular. @ - eugeniobucci@uol.com.br / https://orcid.org/0000-0002-5745-0171.

Recebido em 28.5.2020 e aceito em 19.6.2020.

I Escola de Comunicações e Artes, Universidade de São Paulo, São Paulo, Brasil. 